\title{
Phenotype of vitamin $D$ receptor gene polymorphisms, impact of feeding flaxseed oil, and osteoporosis in ovariectomised diabetic rats
}

\author{
Gamila S. M. El-Saeed ${ }^{1 *}$, Eman A. Elghoroury ${ }^{2}$, Safaa Morsy ${ }^{1}$, Hanan M. Aly ${ }^{3}$ and Hanaa Wafaey ${ }^{1,4}$
}

\begin{abstract}
Background: The vitamin D is involved in a wide variety of biological processes including bone metabolism, regulation of cell proliferation and differentiation. Variations in this endocrine system have, thus, been linked to several common diseases, including osteoporosis, diabetes. The aim of study was to evaluate the effect of flaxseed oil on bone homeostasis and whether changes in the levels of the bone formation markers are related to vitamin $D$ receptor (VDR) gene polymorphisms i.e. Bsm1 and Fok1 which have been studied by the restriction fragment length polymorphism (RFLP) technique.

Results: The study included rats were classified in groups as control, diabetic, diabetic received flaxseed oil in the diet, ovariectomised (ovx), and ovx-diabetic received flaxseed oil in the diet.

Insulin growth factor-1 (IGF-1) urinary deoxypyridinoline (DPD), and osteocalcin were increased (1.470 \pm 88.1$),(160$ $\pm 7.11),(21.25 \pm 2.33)$ respectively in ovx. and have significantly positive correlation $(p<0.05)$ : their lowest levels were detected. Upon adding flaxseed oil. Bone mineral density (BMD) and content (BMC) were reduced $(0.061 \pm 0$. 0046), (0.041 \pm .0048$)$ in all groups and increased $(0.070 \pm 0.0046),(0.063 \pm 0.0045)$ upon adding flaxseed oil which have a ratio of $13.90 \pm 0.01: 21.10 \pm 0.40$ and there is correlation between bone marker and gene polymorphism after receiving flaxseed oil.
\end{abstract}

Conclusion: Diabetes has more pronounced effect on bone health than ovariectomy, and there was effect of gene and flaxseed oil has beneficial effect on the prevention of osteoporosis.

Keywords: Osteoporosis, Diabetes, Flaxseed oil, Bone, Rats, , Vitamin D receptor gene, Polymorphisms, Fok1, Bsm1

\section{Background}

Osteoporosis is a relatively widespread bone disorder, associated with low bone mass density (BMD) and increased risk of bone fractures. Many studies have elucidated that genetic variants may have correlation with the incidence and severity of osteoporosis. Polymorphism and allelic variations in the vitamin D receptor (VDR) gene have been studied for their impact on osteoporosis (Zahra et al. 2014). Investigators have found that female offspring of osteoporotic patients have

\footnotetext{
* Correspondence: ggamilaa@yahoo.com

'Department of Medical Biochemistry, National Research Centre, El-Bohouth Street, Dokki, PO Box 12622, Cairo, Egypt

Full list of author information is available at the end of the article
}

lower bone density in comparison with that of those with normal mothers (Baudoin et al. 2002). Genetic effect on the skeletal system could take place through controlling body uptakes and intakes, i.e., urinary calcium excretion, or defective bone metabolism due to genetic disorders (Ebeling et al. 2013). The trans-cellular pathway of calcium absorption mainly depends on the action of calcitrol and the intestinal VDR. It takes place in the duodenum where the VDR are intensely expressed. Thus the expression of VDR gene may have high impact on calcium absorption (Nele et al. 2011; Xue and Fleet, 2009).

Some studies (Demay 2013; Han et al. 2016) found that in mice with deleted VDR, there is a very obvious 
loss in active $\mathrm{Ca}$ absorption efficiency in the small intestine $(>70 \%)$ as well as reduced expression of the molecular markers of intestinal $\mathrm{Ca}$ absorption. This may lead to clearing out of the critical functions of VDR in bone, i.e., osteoblast formation suppression as well as bone growth (Xue and Fleet 2009). Skeletal bone diseases such as multiple sclerosis (MS), osteoporosis, and vitamin D-dependent rickets type II were found to be affected by vitamin D receptor gene polymorphism (Rosset et al. 2015). Above 100 restriction endonuclease recognition sites have been recognized in VDR gene, some of them are polymorphisms such as Fok1, Bsm1, and Apa1 (Zahra et al. 2014).

As regards Fok1 polymorphisms, BMD has been found to decrease in some studies (Rosset et al. 2015; Kanan 2013; Zahra et al. 2015) but not in others (Kanan 2013), whereas Bsm1, several small studies evaluating Bsm1 have reported significant associations with osteoporosis (Zahra et al. 2015; Barr et al. 2010; Ames et al. 1999).

The VDR genotype polymorphism could also have a role in the process of insulin resistance, either insulin secretion (the Apa1 VDR polymorphism) or resistance (the Bsm1 VDR polymorphism) (Mackawy and Badawi 2014).

Analyzing studies on VDR null mice are paradoxical, as some groups have proved to have glucose intolerance (Chen et al. 2015) while others found it normal. The background of the mouse in which the VDR deletion is introduced seems to be of critical importance. Recently, reports declared that $\beta$-cell function in islets from VDR null mice was normally functioning (Mathieu et al. 2001; Gysemans et al. 2008).

Resemblances were found among the immune, cardiovascular, and muscle phenotype of VDR-resistant mice and that in humans with vitamin D deficiency (Roger et al. 2008).

To emphasize the liaison between osteoporosis, diabetes, VDR gene polymorphisms (Fok1, Bsm1), and the influence of flaxseed oil on either postponing or inhibiting the progress of osteopenia in ovx rats, we did this study.

Vitamin D, through its receptors, has a major role in calcium homeostasis as it adjusts bone cell construction and differentiation, calcium captivation, and secretion of parathyroid hormone (PTH) (Stuart 2002). It has non skeletal actions, such as its role in amending the threat of cardio metabolic consequences in different diseases, such as diabetes mellitus (DM), hypertension, and cardiovascular disease (Chih-Chien et al. 2012).

Studies on null mice showed the importance of the $\mathrm{Ca} / \mathrm{P}$ ratio in the rescue diet for bone mineralization as it affected intestinal calcium and phosphorus transport through VDR (Masuyama et al. 2001). Advances in information about the genetic profile of osteoporosis are of great value, because they explain the aspect of developing genetic maps for the evaluation of fracture risk and also help in defining the molecular basis that could be used as targets for designing new therapeutics to prevent and treat osteoporosis.

The aim of this work was to evaluate the effect of flaxseed oil on bone homeostasis and whether changes in the levels of the bone formation markers are related to VDR gene polymorphisms, i.e., Bsm1 and Fok1, which have been studied by the restriction fragment length polymorphism (RFLP) technique.

\section{Methods}

About 75 female white albino rats $(200 \pm 20$ g) were randomly chosen from the animal House of the National Research Center, Cairo. The rats were acclimated to a basal diet that was prepared in the laboratory of the National Research Center, according to the method mentioned by Picherit et al. (2000) for two days before the experiment started. The rats were housed individually at $25{ }^{\circ} \mathrm{C}$ with $12 \mathrm{~h}$ of light/dark in metallic cages, and they had free access to water throughout the study. The study was approved by the ethical committee of the National Research Centre.

\section{Design of the experiment}

The animals were randomly distributed into the following groups:

1. Normal control rats, which were fed on basal diet.

2. Diabetic rats, which were fed on basal diet.

3. Diabetic rats, which were fed flaxseed instead of corn oil.

4. Non-diabetic rats, which were ovariectomised (ovx), fed on basal diet.

5. Ovx diabetic rats, which were fed on flaxseed oil in the diet instead of corn oil.

All rats were sacrificed at 8 weeks after induction of diabetes.

\section{Surgical procedure}

About 20 rats were bilaterally ovx-operated under light anesthesia according to the method of Goseki et al. (1995).

\section{Induction of diabetes}

About 45 rats were rendered diabetic 2 weeks after ovariectomy with a subcutaneous injection of 45$50 \mathrm{mg} \mathrm{kg} /$ body weight streptozotocin (Sigma, Madrid, Spain) that was dissolved in $5 \mathrm{ml}$ sodium citrate buffer $(\mathrm{pH} 4.5)$. The rats were considered diabetic with fasting blood glucose more than $250 \mathrm{mg} \mathrm{dl} / 1$. An equal volume of sodium citrate buffer was subcutaneously injected in another group that was used as normal controls. 


\section{Urine collection}

Eight weeks after streptozotocin injection, seven rats from each group were individually housed in metabolic cages and allowed to adapt for $48 \mathrm{~h}$. Following this, 24-h urine collections were obtained. Urine was centrifuged and then the samples were frozen at $-20{ }^{\circ} \mathrm{C}$ until used.

\section{Blood collection}

After 60 days, the animals were anesthetized by diethyl ether and the blood was withdrawn from the orbital vein (Hem et al. 1998). The blood was collected in clean polypropylene tubes, which were left to clot at $37^{\circ} \mathrm{C}$ for $10 \mathrm{~min}$, then centrifuged and sera were separated. All sera were frozen at $-20{ }^{\circ} \mathrm{C}$ until used.

\section{Tissue collection}

The tissue of different groups were removed and frozen at $-20{ }^{\circ} \mathrm{C}$ until used to extract DNA.

\section{Biochemical parameters}

Serum calcium, phosphorus, creatinine, and alkaline phosphatase were measured by using the automated clinical chemistry analyzer Olympus AU 400 analyzer.

\section{Bone formation markers}

Plasma osteocalcin and IGF-1 were measured by using ELISA technique (kits derived from Immunodiagnostic Systems Limited, UK) (Baxter et al. 1989; Price et al. 1981).

\section{Bone resorption marker}

DPD was measured using ELISA technique (kits derived from Quidal, USA) (Hesley et al. 1998). Creatinine was measured for determination of DPD.

\section{DEXA analysis for bones}

The rats were dissected, and the excised femurs were cleaned from the surrounding musculature. These bones were weighed, and their length measured; they were stored in saline solution to enhance scanning resolution using Norland XR-46 (3.9.6/2.3.1).

\section{Flaxseed analysis}

Two samples of flaxseed oil were purchased from two different sources and were then analyzed to confirm the ratio of both linoleic (the parent compound of omega-6) and linolenic acids (the parent compound of omega-3). In this procedure, the methylation process was done in one step. The methylated fatty acids were separated using Hewlett Packard gas chromatography system (HP6890) USA; 5\% Phenyl Methyl Solixane capillary column was used with length $30 \mathrm{~m}$, diameter $320 \mu \mathrm{m}$ and film thickness $0.25 \mu \mathrm{m}$. Initial temperature was $70{ }^{\circ} \mathrm{C}$, initial time $2 \mathrm{~min}$, rate $8{ }^{\circ} \mathrm{C} / \mathrm{min}$, final temperature $240^{\circ}$ $\mathrm{C}$, and final time $20 \mathrm{~min}$. Detector temperature was
$300{ }^{\circ} \mathrm{C}$, and injector (Splitless) temperature was $250{ }^{\circ} \mathrm{C}$. Flow rate was $20 \mathrm{ml} / \mathrm{min}$ and pressure was $7.62 \mathrm{psi}$. With each sample, an internal saturated $\mathrm{C} 17$ was used. With each run of samples, a multi-standard of methylated PUFAs was used. Chromatograms of each day consisted of the multi-standard together with the samples of that day. The peak area of each fatty acid in the sample was identified from the retention time of that fatty acid in the multi-standard that was worked on the same day. The identified fatty acids were calculated as percentage of the total fatty acids separated on the chromatogram or total fatty acid in milk from the current study.

Methods of determination of method of GC analysis:

Injection volume: one $\mathrm{u}$

Injection mode: split less

Injector temp: $250{ }^{\circ} \mathrm{C}$

Flow rate: $20 \mathrm{ml} / \mathrm{min}$

Total run time: $43 \mathrm{~min}$

Colum type: Agilent Technolojies19091 J-413 (5\%phenyl methyl siloxane) USA.

The results obtained showed a ratio of $13.90 \pm$ $0.01: 21.10 \pm 0.40$.

\section{Tissue collection}

\section{Detection of Bsm1 and Fok1 polymorphisms}

Extraction of DNA from tissue (Sambrook and Russell 2001) was performed using polymerase chain reaction (PCR) amplification and enzymatic digestion of the products with Bsm1 and Fok1. For the Bsm1 polymorphism, $2 \mathrm{mg}$ of genomic DNA was amplified with each of forward primer 5"AAGACTACAAGTAC CGCGTCAGTG and reverse primer 5"AACCAGCGG GAAGAGGTCAAGGG (supplied by Biosynthesis). Polymerase chain reaction was performed with a Bio metra thermoblock, under standard conditions, for 35 cycles, and with $65{ }^{\circ} \mathrm{C}$ as the annealing temperature. After amplification, the PCR product $(0.825 \mathrm{~kb})$ was digested with restriction endonuclease BsmI and electrophoresed in a $1.2 \%$ agarose gel. With the enzyme Bsm1 (Fermentas, Lithuania), the respective genotypes were defined as B (indicating the absence of the restriction site) or $\mathrm{b}$ (indicating the presence of the restriction site). The PCR product for the Bsm1 polymorphism was $825 \mathrm{bp}$, and the restriction fragments were $650 \mathrm{bp}$ and $175 \mathrm{bp}$. For the Fok1 polymorphism, $2 \mathrm{mg}$ of genomic DNA was amplified with each of forward primer 5"GTGACTTTG ACCGGAACGTG-3'and reverse primer 5"ATCA TCTCCCTCTTACGCTG-3'. Products were digested with restriction enzyme BseGI (Fermentas, Lithuania), an isoschizomer of the FokI enzyme, at $55{ }^{\circ} \mathrm{C}$ for 120 min. Fragments were electrophoresed through a 2\% agarose gel containing ethidium bromide, visualized, and photographed. The presence of the FokI restriction site on both alleles (defined before as ff) generates 196-bp 
and 69-bp fragments, whereas the absence (FF) yields one undigested 265-bp fragment. Heterozygous Ff exhibits fragments of $265 \mathrm{bp}, 196 \mathrm{bp}$, and $69 \mathrm{bp}$ (Robert et al. 2001).

The VDR polymorphisms that have been studied using the restriction fragment length polymorphism (RFLP) technique involve Bsm1 (Morrison et al. 1992) and Fok1 polymorphism (Arai et al. 1997; Khan et al. 2014).

\section{Statistical analysis}

Statistical analysis of the results was carried. Normally distributed results were compared using student's $t$ test. Differences among groups were evaluated using one-way ANOVA. Results were expressed as mean $\pm \mathrm{SD}$. $p$ values less than 0.05 were considered statistically significant.

\section{Results}

Table 1 demonstrates the ALP increased level in the studied groups in comparison to the control group, while the ovx group has the highest level (2, 3-fold) compared with the diabetic group. Addition of flaxseed oil to the nourishment of both diabetic and ovx-diabetic groups significantly inhibited the elevation in ALP. Phosphorus significantly decreased in all the study groups in comparison to the control group. Statistical significant increase in phosphorus levels was found among the diabetic rat group with intact ovaries than that of the ovx group.

Calcium and calcium/phosphorus ratio of all groups were found to be significantly elevated as compared with the normal control group. Upon adding flaxseed oil to the diet of both the diabetic and the ovx-diabetic groups, the ratio decrease for the diabetic rats + flaxseed as compared to the diabetic group fed a basal diet.

\section{Bone formation markers}

Osteocalcin level significantly decreased in the diabetic group $(p<0.05)$ and significantly increased $\mathrm{r}(p<0.05)$ in the ovx group when compared with normal. There are significant differences that were registered between the diabetic group and diabetic + flaxseed group, whereas a significant decrease was shown in the ovx-diabetic + flaxseed group as compared with that of the ovx-diabetic rats.

IGF-1 was significantly increased in the ovx group as compared with the other groups. Induction of diabetes significantly reduces IGF-1. Adding flaxseed oil to the diet normalized again IGF-1.

\section{Bone resorption marker}

DPD in urine significantly decreased in groups fed on flaxseed as compared with the control group and significantly increased in the ovx and diabetic groups (Table 2).

Bone mineral content and bone mineral density (Table 3) Adding flaxseed oil to the diet increased both bone mineral content $(B M C)$ and BMD. The results show significant correlation of genetic variants with control BMC $(P<0.05)$, and in diabetic, there is a correlation with BMD, Alk., IGF-1 $(P<0.05)$, but Bsm1 have correlation with ostecalcin $(P<0.05)$ in ovx group. In diabetic + flaxed, folk gene has significant correlation with $\mathrm{ph}, \mathrm{Ca}$, and DPD $(P<0.05)$ where Bsm1 have significant correlation with all bone markers, ph, osteocalcin, IGF-1, DPD, and BMC $(P<0.05)$. In diabetic + cvx + flaxseed, Bsm1 have correlation with all parameter $(P<0.05)$ except $\mathrm{BMC}$ where folk have correlation with alk, BMD, BMC $(P<0.05)$.

\section{Discussion}

Vitamin D is intricate in a wide assortment of biological routes comprising bone metabolism. Activity of vitamin $\mathrm{D}$ is mediated by the vit. $\mathrm{D}$ receptor and vit. D gene polymorphism, thus represents strong positional candidates for many disorder included bone homeostasis (Elkum et al., 2014) (Table 4).

In this study, by using streptozotocin which causes destruction of the pancreatic beta-cells and thus leads to depletion of insulin, the female rats developed diabetes type 1 .The rats were also ovx so that to simulate the menopause females with low estrogen levels. The association of diabetes and osteoporosis was estimated in one group. Assessment of the bone status was studied by measuring the levels of serum bone construction

Table 1 Biochemical parameters level in different groups studied

\begin{tabular}{|c|c|c|c|c|c|}
\hline Parameter & Normal control & Diabetic & Ovariectomised & Diabetic flaxseed & Ovariectomised-diabetic flaxseed \\
\hline Alkaline phosphatase (U/L) & $60 \pm 3.46$ & $80.3 \pm 0.21 a$ & $2.3326 \mathrm{E} 2 \pm 15.19 \mathrm{a}$ & $64.14 \pm 2.41$ & $1.2857 \mathrm{E} 2 \pm 14.28 \mathrm{cc}$ \\
\hline Phosphorus (mg/dl) & $7.12 \pm 0.25$ & $5.48 \pm 0.13 a$ & $4.64 \pm 0.35 a$ & $5.94 \pm 0.140$ & $6.05 \pm 0.37$ \\
\hline Calcium (mg/dl) & $8.98 \pm 0.29 a$ & $10.60 \pm 0.21$ & $9.32 \pm 0.17$ & $10.18 \pm 0.20$ & $10.21 \pm 0.33 c$ \\
\hline Calcium/Phosphorus & $1.22 \pm 0.07$ & $1.93 \pm 0.06$ & $2.01 \pm 0.12 \mathrm{aа}$ & $1.7 \pm 0.03 a$ & $1.68 \pm 0.054 c$ \\
\hline
\end{tabular}

${ }^{\mathrm{a} S i g n i f i c a n t}$ differences at $p<0.05$ vs. normal control

${ }^{b}$ Significant differences at $p<0.05$ vs. diabetic group

'Significant differences at $p<0.05$ vs. ovx-diabetic 
Table 2 Changes in bone formation and resorption parameters in the studied groups

\begin{tabular}{llllll}
\hline Parameter & Normal control & Diabetic & Ovariectomised & Diabetic flaxseed & Ovariectomised-diabetic flaxseed \\
\hline Osteo. $(\mathrm{ng} / \mathrm{L})$ & $16.95 \pm 1.35 \mathrm{aa}$ & $13.48 \pm 0.88 \mathrm{~b}$ & $21.25 \pm 2.33 \mathrm{aa}$ & $14.92 \pm 0.75 \mathrm{a}$ & $15.38 \pm 0.80 \mathrm{c}$ \\
IGF-1 $(\mathrm{ng} / \mathrm{L})$ & $1.3197 \mathrm{E} 3 \pm 30.15 \mathrm{a}$ & $9.0000 \mathrm{E} 2 \pm 55.37 \mathrm{~b}$ & $1.47 \mathrm{E} 3 \pm 88.11 \mathrm{a}$ & $1.3151 \mathrm{E} 3 \pm 227.09 \mathrm{a}$ & $1.3693 \mathrm{E} 3 \pm 47.17 \mathrm{a}$ \\
DPD $(\mathrm{nmol} \mathrm{mmol} / \mathrm{Cr})$ & $1.1383 \mathrm{E} 2 \pm 3.01$ & $1.2640 \mathrm{E} 2 \pm 3.84$ & $1.6080 \mathrm{E} 2 \pm 7.11 \mathrm{a}$ & $1.0157 \mathrm{E} 2 \pm 4.50$ & $1.1141 \mathrm{E} 2 \pm 4.68 \mathrm{cc}$
\end{tabular}

${ }^{\mathrm{a} S i g n i f i c a n t ~ d i f f e r e n c e s ~ a t ~} p<0.05$ vs. normal control

${ }^{\mathrm{b}}$ Significant differences at $p<0.05$ vs. diabetic group

'Significant differences at $p<0.05$ vs. ovx-diabetic

markers IGF-1 and osteocalcin and bone resorption marker deoxypyridinoline. Addition of flaxseed oil (rich in omega-3 fatty acids) to the nourishment of one group of the diabetic and the ovx-diabetic groups aims to test for the role of this oil on either postponing or avoiding the progress of osteopenia in ovx rats.

The link between genetic variants and osteoporosis has been investigated. Polymorphism and allelic variations in the vitamin $\mathrm{D}$ receptor gene (VDR) have been found to be associated with BMD variation (Wu et al. 2016; Roger et al. 2008). This agree with our study.

The findings established a critical role of VDR in growth and bone formation (Wu et al. 2016; Roger et al. 2008). This agree with our finding where there are significant correlation with IGF-1 $(P$ value $=0.009)$. The FokI single nucleotide polymorphism of the transformation start site results in a VDR protein with three amino acids shorter and is not associated with any other VDR polymorphisms (Mostowska et al. 2013).

Three common polymorphisms in the 3 _ region of the VDR gene, located between exons 8 and 9 , are predictable by the restriction enzymes BsmI, ApaI, and TaqI. These were found to be associated with serum level diversity of osteocalcin (the osteoblast explicit protein) and bone mass.

Several researches on vitamin D-deficient animals showed impaired insulin release when cultured isolated islets in vitro and tested in challenge with glucose. By culturing the islets in the presence of high concentrations of $1,25-(\mathrm{OH})_{2} \mathrm{D}$, these changes can be avoided. Moreover, high levels of $1,25-(\mathrm{OH})_{2} \mathrm{D}$ activate insulin synthesis and release upon glucose challenge in pancreatic islets which were isolated from normal animals (Blumberg et al. 2006; Riachy et al. 2001).

Table 3 Level of BMC (g), BMD ( $\mathrm{g} \mathrm{cm} / 2)$ in the studied groups

\begin{tabular}{lll}
\hline Parameter & $\mathrm{BMD}$ & $\mathrm{BMC}$ \\
\hline Normal control & $0.066 \pm 0.0057 \mathrm{a}$ & $0.039 \pm 0.00024 \mathrm{aa}$ \\
Diabetic & $0.061 \pm 0.0046 \mathrm{bb}$ & $0.041 \pm 0.0048 \mathrm{bb}$ \\
Diabetic flaxseed & $0.070 \pm 0.0046 \mathrm{a}$ & $0.063 \pm 0.0045 \mathrm{a}$ \\
Ovariectomised & $0.070 \pm 0.0058 \mathrm{a}$ & $0.105 \pm 0.0015$ \\
Ovariectomised-diabetic flaxseed & $0.080 \pm 0.0036 \mathrm{cc}$ & $0.123 \pm 0.0032 \mathrm{c}$
\end{tabular}

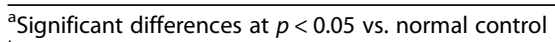

bSignificant differences at $p<0.05$ vs. diabetic group

'Significant differences at $p<0.05$ vs. ovx-diabetic
Results showed that the level of ALP and ph in diabetic rats was reduced. Similar results were previously shown in diabetic rats (Gopalakrishnan et al. 2006), where ALP and Ca were significantly greatly increased above all groups. Total serum ALP levels including the bone ALP are released from the bone; this may clear the cause of the significant increase of ALP in ovx group of rats as a response to decrease of estrogen. The reduced results thereafter in ALP in ovx-diabetic could be due to the decrease in osteoblastic activity in diabetic rats. Once the rats were nourished with flaxseed, the three parameters were revolved to be within the high-normal variety. Thus $\mathrm{Ca}: \mathrm{Ph}$ ratio was increased. Rise of $\mathrm{Ca}: \mathrm{P}$ in diet was proposed to prevent bone damage and upsurge intestinal Ca captivation in ovx rats (Ghodsi et al. 2016). Contradicting to our data, Gopalakrishnan et al. (2006) showed that serum ALP activity was amplified up to threefold in diabetic rats. More duration or increase in concentration of flaxseed may be needed for $\mathrm{Ca}: \mathrm{Ph}$ ratio to return to normal levels.

In rats with diabetes, osteocalcin and IGF-1 were significantly reduced. Studies showed that diabetes may lead to lower bone turnover index and impairment of both osteoblastic maturity and activity (Ghodsi et al. 2016).

Diabetic rats which were fed on flaxseed oil were found to have elevated levels of osteocalcin and IgF-1; the rate of bone turnover in diabetic rats was elevated as a result of feeding flaxseed, thus compensating for the extreme estrogen deficiency that occurred by ovariectomy. Studies found that the increased levels of bone formation biomarkers in ovx animals could be due to the osteoblastic activity in response to estrogen deficiency. The levels of the two parameters were nearly

Table 4 Comparison of vitamine D receptor genes between groups

\begin{tabular}{lll}
\hline Parameter & bsm1 & fok \\
\hline Normal control & $\mathrm{BB}(33.3 \%)$ & $\mathrm{FF}(50 \%) \mathrm{aa}$ \\
Diabetic & $\mathrm{Bb}(66.6 \%) \mathrm{bb}$ & $\mathrm{Ff}(50 \%) \mathrm{b}$ \\
Diabetic flaxseed & $\mathrm{Bba}$ & $\mathrm{FF}$ \\
Ovariectomised & $\mathrm{BBa}$ & $\mathrm{Ff}$ \\
Ovariectomised-diabetic flaxseed & $\mathrm{Bbcc}$ & $\mathrm{FfC}$ \\
\hline
\end{tabular}

${ }^{a}$ Significant differences at $p<0.05$ vs. normal control

bSignificant differences at $p<0.05$ vs. diabetic group

cSignificant differences at $p<0.05$ vs. ovx-diabetic 
normal by feeding rats flaxseed oil. Also, dietary $(n-3$ LCPUFA) decrease the deterioration in bone mass due to menopause in females (Kasonga et al. 2015).

In this study, bone resorption was examined by the assessment of the level of urinary DPD in relation to creatinine. It showed significant increase in the group of diabetic rats and the ovx group as well. While in the ovx group of rats which were fed on flaxseed oil instead of traditional corn oil, their bone resorption was turned normal (Longo and Ward, 2016).

Different protocols of the experiments could explain the discrepancy of the results. In this study, diabetic rats, $\mathrm{BMD}$, which was assessed by using dual energy X-ray absorptiometry (DEXA), showed decreased results than those of the normal control group. Upon replacing flaxseed oil in the diet, both BMD and BMC turned higher.

Further experimental period may have been required to show more pronounced effect on BMC. Weiler et al. (2007) showed similar results. They found that BMD were. $2.2 \%$ higher in female rats fed flaxseed oil in comparison with that of the control rats.

In this study, VDR gene Fok1 and Bsm1 were significantly related to bone marker values in rats.

In conclusion, diabetes, ovariectomy, and the general phenotype of whole body are influenced strongly by vitamin D receptors. Fok1 and Bsm1 gene polymorphisms may be contributing factors in bone loss formation and mineralization in the bone. Our study and previous experimental studies as well proved the effective impact of $n-3$ fatty acids in the form of flaxseed on improving skeletal formation and avoiding osteoporosis. However, further investigations both on animals and humans are needed to be performed to confirm the effectiveness of dietary flaxseed oil in improving bone health and avoiding osteoporosis.

\section{Acknowledgements}

We would like to acknowledge the National Research centre for funding our work.

\section{Funding}

The work was funded by the National Research centre.

\section{Availability of data and materials}

Not applicable.

\section{Authors' contributions}

All authors contributed to the study design, laboratory analysis, and writing of the manuscript. All authors revised the final manuscript and approved it.

\section{Ethics approval}

The study was approved by the ethical committee of the National Research Centre.

\section{Consent for publication}

Not applicable.

\section{Competing interests}

The authors declare that they have no competing interests.

\section{Publisher's Note}

Springer Nature remains neutral with regard to jurisdictional claims in published maps and institutional affiliations.

\section{Author details}

'Department of Medical Biochemistry, National Research Centre, El-Bohouth Street, Dokki, PO Box 12622, Cairo, Egypt. ${ }^{2}$ Clinical Pathology, National Research Centre, Cairo, Egypt. ${ }^{3}$ Cell Biology, National Research Centre, Cairo, Egypt. ${ }^{4}$ Biochemistry Department, College of Science, King Abdulaziz University, Jeddah, Saudi Arabia.

Received: 18 July 2018 Accepted: 6 August 2018

Published online: 11 October 2018

\section{References}

Ames SK, Ellis KJ, Gunn SK, Copeland KC, Abrams SA (1999) Vitamin D receptor gene Fok1 polymorphism predicts calcium absorption and bone mineral density in children. J Bone Miner Res 14:740-746

Arai H, Miyamoto K, Taketani Y et al (1997) A vitamin D receptor gene polymorphism in the translation initiation codon: effect on protein activity and relation to bone mineral density in Japanese women. J Bone Miner Res 12:915-921

Baxter RC, Martin JL and Beniac VA (1989) 'High molecular weight insulin-like growth factor binding protein complex', Journal of Biological chemistry 264:11843-11848.

Barr R, Macdonald H, Stewart A, McGuigan F, Rogers A, Eastell R, Felsenberg D, Glüer C, Roux C, Reid D (2010) Association between vitamin D receptor gene polymorphisms, falls, balance and muscle power: results from two independent studies (APOSS and OPUS). Osteoporos Int 21:457-466

Baudoin C, Cohen-solal ME, Beaudreuil J, DE VERNEJOUL MC (2002) Genetic and environmental factors affect bone density variances of families of men and women with osteoporosis. J Clin Endocrinol Metab 87(5):2053-2059

Blumberg JM, Tzameli I, Astapova I, Lam FS, Flier JS, Hollenberg AN (2006) Complex role of the vitamin $\mathrm{D}$ receptor and its ligand in adipogenesis in 3T3-L1 cells. J Biol Chem 281:11205-11213

Chen S, Villalta SA, Agrawal DK (2015) FOXO1 mediates vitamin D Deficiency induced insulin resistance in skeletal muscle. J Bone Miner Res 31:3

Chih-Chien S, Min-Tser L, Kuo-Cheng L, Chia-Chao W (2012) Role of Vitamin D in Insulin Resistance. J Biomed Biotechnol 2012:634195 P.11

Demay MB (2013) Physiological insights from the vitamin D receptor knockout mouse. Calcif Tissue Int 92(2):99-105

Ebeling PR, Daly RM, Kerr DA, Kimlin MG (2013) Building healthy bones throughout life: an evidence-informed strategy to prevent osteoporosis in Australia. Med J Aust 2(1):1

Elkum N, Alkayal F, Ali MM, Melhem M, Al-Arouj M, Bennakhi A, Behbehani K, Alsmadi O, Jehad J (2014) Vitamin D insufficiency in Arabs and South Asians positively associates with polymorphism in GC and CYP2R1 genes. PLOS ONE 9(11):e113102

Ghodsi M, Larijani B, Keshtkar AA, Nasli-Esfahani E, Alatab S, Mohajeri-Tehrani MR (2016) Mechanisms involved in altered bone metabolism in diabetes: a narrative review. J Diabetes Metab Disord 15:52

Gopalakrishnan V, Arunakaran J, Aruldhas MM, Srinivasan N (2006) Effects of streptozotocin-induced diabetes mellitus on some bone turnover markers in the vertebrate of ovary-intact and ovariectomized adults rats. Biochem Cell Biol 84:728-736

Goseki MS, Omi M, Yamamoto A, Oida S, Ezawa I, Sasaki S (1995) Ovariectomy decreases osteogenic activity in rat bone. Nutr Sci Vitaminol 42:55-67

Gysemans C, Van Etten E, Overbergh L, Giulietti A, Eelen G, Waer M, Verstuyf A, Bouillon R, Mathieu C (2008) Unaltered diabetes presentation in NOD mice lacking the vitamin D receptor. Diabetes 57:269-275

Han J, Wang J, Chen G, Qu H, Zhang J, Shi C, Yan Y, Cheng Y (2016) Effects of calcium to non-phytate phosphorus ratio and different sources of vitamin D on growth performance and bone mineralization in broiler chickens. R Bras Zootec 45:1 Viçosa Jan

Hesley RP, Shepard KA, Jenkins DK and Riggs BL (1998) 'Monitoring estrogen replacement therapy and identifying rapid bone losers with an immunoassay for deoxypyridinoline', Osteoporosis International, Vol. 8, pp. 159-164.

Hem A, Smith AJ and Solberg P (1998) 'Saphenous vein puncture for blood sampling of the mouse, rat, hamster, gerbil, guineapig, ferret and mink', Laboratory Animals, Vol. 32, pp.364-368 
Kanan RM (2013) The effect of Fokl vitamin D receptor polymorphism on bone mineral density in Jordanian perimenopausal women. Indian J Hum Genet 19(2):233-238

Kasonga AE, Deepak V, Kruger MC, Coetze M (2015) Arachidonic acid and docosahexaenoic acid suppress osteoclast formation and activity in human CD14+ monocytes, in vitro. PLoS ONE 10(4):e0125145

Khan MI, Bielecka ZF, Najm MZ, Bartnik E, Czarnecki JS, Czarnecka AM, Szczylik C (2014) Vitamin D receptor gene polymorphisms in breast and renal cancer: current state and future approaches. Int J Oncol 44(2):349-363

Longo AB, Ward WE (2016) Providing flaxseed oil but not menhaden oil protects against OVX induced bone loss in the mandible of Sprague-Dawley rats. Nutrients 8(10):597

Mackawy AMH, Badawi MEH (2014) Association of vitamin D and vitamin D receptor gene polymorphisms with chronic inflammation, insulin resistance and metabolic syndrome components in type 2 diabetic Egyptian patients. Meta Gene 2:540-556

Masuyama R, Nakaya Y, Tanaka S, Tsurukami H, Nakamura T, Watanabe S, Yoshizawa T, Kato S, Suzuki K (2001) Dietary phosphorus restriction reverses the impaired bone mineralization in vitamin $\mathrm{D}$ receptor knockout mice. Endocrinology 142:494-497

Mathieu C, van Etten E, Gysemans C, Decallonne B, Kato S, Laureys J, Depovere J, Valckx D, Verstuyf A, Bouillon R (2001) In vitro and in vivo analysis of the immune system of vitamin D receptor knockout mice. J Bone Miner Res 16:2057-2065

Morrison NA, Yeoman R, Kelly PJ, Eisman JA (1992) Contribution of trans-acting factor alleles to normal physiological variability: vitamin D receptor gene polymorphism and circulating osteocalcin. Proc Natl Acad Sci U S A 89:6665-6669

Mostowska A, Sajdak S, Pawlik P, Lianeri M, Jagodzinski PP (2013) Vitamin D receptor gene BSM1 and Fok1 polymorphism in relation to ovarian cancer risk in the Polish population. Genet Test Mol Biomarkers 17(3):183-187

Nele S, Tobias M, Mariusz PK, Annette L, Alois B (2011) Expression patterns of intestinal calcium transport factors and ex-vivo absorption of calcium in horses. BMC Vet Res 7:65

Picherit C, Coxam V, Pelissero CB, Coulibaly SK, Davicce MJ, Lebeque P (2000) Daidzein is more efficient than genistein in preventing ovariectomy induced bone loss in rats. Nutrition 130:1675-1681

Price, P.A., Williamson, M.K. and Lothringer, J.W. (1981) 'Origin of the vitamin Kdependent bone protein found in plasma and its clearance by kidney and bone', Journal of biological chemistry, Vol. 256, pp. 12760-12766.

Riachy R, Vandewalle B, Belaich S, Kerr-Conte J, Gmyr V, Zerimech F, d'Herbomez M, Lefebvre J, Pattou F (2001) Beneficial effect of 1,25 dihydroxyvitamin D3 on cytokine-treated human pancreatic islets. J Endocrinol 169:161-168

Robert FK, Marie S, Michele EG, Geoffrey BP, John KB, Eric SO (2001) Phenotypic characterization of mice bred for high and low peak bone mass. J Bone Miner Res 16(1):63-71

Roger B, Geert C, Lieve V, Evelyne VE, Annemieke V, Hilary FL, Ln L, Chantal M, Marie D (2008) Vitamin D and human health: lessons from vitamin D receptor null mice. Endocr Rev 29(6):726-776

Rosset LSMBC, Pereira EAFS, Ribeiro PIZ, Scalco R, Bittar CM, Netto CBO, Rucatti GG, Chies JA, Camey SA, Prolla PA (2015) Vitamin D status and VDR genotype in NF1 patients: a case-control study from southern Brazil. Int J Endocrinol 2015:402838

Sambrook J, Russell DW (2001) Molecular cloning, a laboratory manual. Cold Spring Harbor Laboratory Press, Cold Spring Harbor, NewYork

Stuart HR (2002) Genetic control of susceptibility to osteoporosis. J Clin Endocrinol Metab 87(6):2460-2466

Weiler HA, Kovacs H, Nitschmann E, Bankovic-Calic N, Aukema H, Ogborn M (2007) Feeding flaxseed oil but not secoisolariciresinol diglucoside results in higher bone mass in healthy rats and rats with kidney disease. Prostaglandins Leukot Essent Fatty Acids 76:269-275

Wu J, Shang P, Yang S, Fu P, Ling HY, Sh HS, Lu JM (2016) Association between the vitamin $D$ receptor gene polymorphism and osteoporosis. Biomed Rep 5(2):233-236

Xue Y, Fleet JC (2009) Intestinal vitamin D receptor is required for normal calcium and bone metabolism in mice. Gastroenterology 136:1317-1327
Zahra M, Abbasali K, Fateme F, Mehdi E, Mahsa MA, Mostafa G, Patricia K, Mahboubeh D, Mina ER, Bagher L (2015) Prevalence of osteoporosis and vitamin D receptor gene polymorphisms (Fokl) in an Iranian general population based study (Kurdistan) (IMOS). Med J Islam Repub Iran 29:238

Zahra M, Fateme F, Mehdi E, Mahsa MA, Patricia K, Mahboubeh D, Reza NZ, Abbasali K, Hamid RB (2014) Association between vitamin D receptor gene polymorphisms (Fok1 and Bsm1) and osteoporosis: a systematic review. J Diabetes Metab Disord 13:98

\section{Submit your manuscript to a SpringerOpen ${ }^{\circ}$ journal and benefit from:}

- Convenient online submission

- Rigorous peer review

- Open access: articles freely available online

- High visibility within the field

- Retaining the copyright to your article

Submit your next manuscript at $\boldsymbol{\nabla}$ springeropen.com 